\title{
PENYELESAIAN SENGKETA PERBANKAN SYARIAH \\ DI PERADILAN AGAMA MENURUT PASAL 55 AYAT (1) \\ UNDANG-UNDANG NOMOR 21 TAHUN 2008 \\ TENTANG PERBANKAN SYARIAH \\ (Studi Kasus Putusan Perkara Nomor : 2860/PDT.G/2013/PA.MR.)
}

\author{
Rizki Kurniawan ${ }^{1}$, Ayu Intan ${ }^{2}$ \\ 1. Dosen Fakultas Hukum Universitas Gresik \\ 2. Mahasiswa Fakultas Hukum, Universitas Gresik
}

\begin{abstract}
ABSTRAK
Rumusan masalah dalam penelitian ini adalah: 1.) Bagaimana Mekanisme Penyelesaian Sengketa Perbankan Syariah dalam Lingkungan Peradilan Agama menurut Pasal 55 Ayat (1) Undang-Undang Nomor 21 Tahun 2008 atas Perkara Nomor : 2860/Pdt.G/2013/PA.Mr ? 2. Bagaimana pertimbangan Hakim dalam memutus Sengketa Perbankan Syariah di Peradilan Agama atas perkara Nomor: 2860/pdt.G/2013/PA.Mr?Penelitian ini menggunakan metode Hukum Normatif, yang difokuskan untuk mengkaji penelitian hukum positif yang berhubungan dengan perbankan syariah sesuai dengan Pasal 55 Undang-Undang Nomor 21 Tahun 2008 tentang Perbankan Syariah atas putusan Pengadilan Agama Mojokerto Nomor : 2860/Pdt.G/2013/PA.Mojokerto. Bahan hukum primer (primary resource atau authoritative records) berupa 1) Undang-Undang Nomor 48 Tahun 2009 tentang Kekuasaan Kehakiman; 2) Inpres No. 1 Tahun 1991 tentang Kompilasi Hukum Islam ; dan 3) Putusan Perkara Nomor 2860/Pdt.G/2013/PA.Mr. Hasil penelitian diketahui 1) Menurut Undang undang Nomor 3 Tahun 2006 tentang Perubahan Undang undang Nomor 7 Tahun 1939 Tentang Peradilan Agama. Pengadilan Agama mempunyai kewenangan dalam menyelesaiakan sengketa ekonomi syariah. Penyelesaian sengketa melalui pengadilan (litigasi) adalah salah satu alternatif yang diperbolehkan oleh hukum, 2) Keberadaan perlindungan hukum bagi nasabah bank syariah atas perkara nomor 2860/Pdt.G/2013/PA.Mr, dari analisis dapat dikemukakan bahwa masih terdapat realita perlindungan hokum bagi nasabah yang berpekara dalam perkara ekonomi syariah masih belum optimal mendapatkan perlindungan hokum oleh pihak yang berwenang menanganinya, hal ini juga dikeranakan masih banyak nasabah yang belum memahami penyelesaian hukum terhadap perkara hukum yang akan terjadi bila berkaitan dengan ekonomi syariah..
\end{abstract}

Kata Kunci: Sengketa, Perbankan Syariah, dan Undang-Undang Nomor 21 Tahun 2008

\section{PENDAHULUAN}

\subsection{Latar Belakang Masalah}

Transaksi (akad) Perbankan Syariah yang dilakukan adalah berlandaskan Syariat Islam, sehingga sudah pada tempatnya apabila terjadi persengketaan (dispute), maka akan menentukan lembaga mana yang akan menangani. Setelah adanya amandemen oleh DPR RI dan Presiden terhadap Undang-Undang Nomor 7 Tahun 1989 dengan Undang-Undang Nomor 3 Tahun 2006 dan terakhir dengan Undang-Undang Nomor 50
Tahun 2009 tentang Peradilan Agama dirasa sudah tepat, dengan memberikan kewenangan mutlak (absolut) kepada lembaga Peradilan Agama untuk menerima, memeriksa, mengadili dan menyelesaikan perkara sengketa Bank Syariah ${ }^{1}$

Ketentuan tentang penyelesaian Sengketa Perbankan Syariah diatur dalam ketentuan Pasal 55 Undang-Undang Nomor 21 Tahun 2008

\footnotetext{
${ }^{1}$ Ahmad Mujahidin, Prosedur Sengketa Ekonomi Syariah di Indonesia, Ghalia Indonesia, Bogor, 2010, hal 16-17.
} 
tentang Perbankan Syariah, Dalam Pasal 55 ayat (1) tersebut jelas menyatakan bahwa Lembaga yang berwenang menyelesaikan Sengketa Perbankan Syariah adalah Peradilan Agama.

Pelaksanaan penelitian ini difokuskan dengan pembatasan pada Putusan Perkara 2860/Pdt.G/2013/PA.Mr, berkaitan dengan Nasabah yang melakukan Akad Pembiayaan Murabahah di Bank BRI Syariah Mojokerto, Jawa Timur. dimana pada kasus tersebut penyelesaian sengketanya dilakukan melalui Badan Arbitrase Syariah Nasional, padahal Nasabah tidak mengetahui tentang Pasal Penyelesaian Perselisihan, sebagaimana terdapat dalam Pasal 19 Akad Perjanjian Pembiayaan tersebut, sehingga Nasabah mengajukan perkaranya ke Pengadilan Agama Mojokerto.

\subsection{Rumusan Masalah}

1. Bagaimana Mekanisme Penyelesaian Sengketa Perbankan Syariah dalam Lingkungan Peradilan Agama menurut Pasal 55 Ayat (1) Undang-Undang Nomor 21 Tahun 2008 atas Perkara Nomor : 2860/Pdt.G/2013/PA.Mr ?

2. Bagaimana pertimbangan Hakim dalam memutus Sengketa Perbankan Syariah di Peradilan Agama atas perkara Nomor: 2860/pdt.G/2013/PA.Mr?

\subsection{Tujuan Penelitian}

1. Untuk mengetahui Penyelesaian Sengketa Perbankan Syariah yang dilakukan oleh Pengadilan Agama dalam Lingkungan Peradilan Agama menurut Pasal 55 Ayat (1) Undang-Undang Nomor 21 Tahun 2008 atas Perkara Nomor : 2860/Pdt.G/2013/PA.Mr.

2. Untuk mengetahui Pertimbangan Hakim dalam memutus Sengketa Perbankan Syariah di Peradilan Agama atas perkara Nomor: 2860/pdt.G/2013/PA.Mr.

\subsection{Manfaat Penelitian}

1. Manfaat Teoritis, hasil dari penelitian ini diharapkan dapat bermanfaat bagi penulis, Mahasiswa, dan Masyarakat, yaitu dapat mengetahui dan memberikan tambahan wawasan pengetahuan terkait bentuk Penyelesaian Sengketa bagi Nasabah Bank BRISyariah atas putusan dari perkara Nomor: 2860/Pdt.G/2013/PA.Mr.

2. Manfaat Praktis, Bagi Nasabah Bank Syariah dan Dunia Usaha dalam melakukan transkasi pembiayaan dengan bank Syariah agar dapat mengetahui dan memberikan tambahan wawasan pengetahuan terkait bentuk Pertimbangan Hakim dalam memutus Sengketa Perbankan Syariah di Peradilan Agama perkara Nomor : 2860/Pdt.G/2013/PA.Mr.

\section{TINJAUAN PUSTAKA}

\subsection{Pengertian Bank Syariah}

Bank Indonesia mendefinisikan Bank Syariah sebagai berikut: ${ }^{2}$ Bank syariah ialah bank yang berasaskan, antara lain, pada asas kemitraan, keadilan, transparansi dan universal serta melakukan kegiatan usaha perbankan berdasarkan prinsip syariah ${ }^{3}$.

Kegiatan bank syariah merupakan implementasi dari prinsip ekonomi Islam dengan karakteristik, antara lain sebagai berikut :

a. Pelarangan riba dalam berbagai bentuknya;

${ }^{2}$ Bank Indonesia, Pedoman Akuntansi Perbankan Syariah Indonesia, Jakarta.

${ }^{3}$ Muhammad Abdullah Al-ArabiPetunjuk Praktis Menjalankan Syariat Islam dalam Bermuamalah yang Sah Menurut Hukum Nasional, Jakarta, Studia Press, 2000. 
b. Tidak mengenal konsep nilai waktu dari uang (time value of money);

c. Konsep uang sebagai alat tukar bukan sebagai komoditas;

d. Tidak diperkenankan melakukan kegiatan yang bersifat spekulatif;

e. Tidak diperkenankan menggunakan dua harga untuk satu barang; dan

f. Tidak diperkenankan dua transaksi dalam satu akad ${ }^{4}$

\subsection{Mekanisme Penyelesaian Sengketa Perbankan Syariah}

Penyelesaian sengketa perbankan syariah melalui mekanisme penyelesaian sengketa alternatif di luar pengadilan seperti musyawarah, mediasi, dan arbitrase syariah merupakan langkah yang tepat dan layak untuk diapresasi. Akan tetapi, masalah muncul ketika Pengadilan Negeri juga diberikan kewenangan yang sama dalam menyelesaikan sengketa perbankan syariah. ${ }^{5}$

Terjadi dualisme penyelesaian sengketa dan ketidakpastian hukum serta tumpang tindih kewenangan dalam menyelesaikan suatu perkara yang sama oleh dua lembaga peradilan yang berbeda. Padahal, kewenangan ini jelas merupakan kewenangan Pengadilan Agama sebagaimana diatur dalam Pasal 49 (i) UU No. 3 Tahun 2006 tentang Peradilan Agama. ${ }^{6}$

\section{METODE PENELITIAN}

\subsection{Rancangan Penelitian}

Tipe penelitian yang dipergunakan dalam penelitian ini adalah Penelitian Hukum Normatif (Yuridis Normatif). PenelitianHukum Normatif

\footnotetext{
4 Ibid

5 ThalisNoor CJurnal Ekonomi Syariah Indonesia, Volume I, No.2 Desember 2011-16

${ }^{6}$ http://business-law.binus.ac.id/2015/02/17/ penyelesaian-sengketa-perbankan-syariah-diindonesia-bagian-1-dari-2-tulisan
}

adalah penelitian hukum yang dilakukan dengan cara meneliti bahan pustaka atau bahan hukum sekunder, sebagai pendukung bahan hukum primer berupa peraturan perundang-undangan dan putusan-putusan pengadilan. $^{7}$

\subsection{Sumber Bahan Hukum}

Bahan hukum primer berupa peraturan perundang-undangan dan Putusan Pengadilan yang berkaitan dengan ekonomi syariah dan Penyelesaian Sengketa antara lain:

1) Reglemen Indonesia yang diperbaharui (HIR)

2) Undang-Undang Nomor 7 Tahun 1989 tentang Peradilan Agama sebagaimana telah diubah dan ditambah dengan Undang-Undang Nomor 3 Tahun 2006 dan Perubahan kedua dengan Undang-Undang Nomor 50 Tahun 2009;

3) Undang-Undang Nomor 30 tahun 1999 Tentang Arbritase dan Alternatif Penyelasaian Sengketa ;

4) Undang-Undang Nomor 48 Tahun 2009 tentang Kekuasaan Kehakiman;

5) Inpres No. 1 Tahun 1991 tentang Kompilasi Hukum Islam ; dan

6) Putusan Perkara

Nomor 2860/Pdt.G/2013/PA.Mr.

Bahan hukum sekunder (secondary resource atau authoritative records) seperti literature, hasil penelitian, laporan perkara, artikel, jurnal hukum ${ }^{8}$.

Bahan hukum tersier (tertiary resource) berupa : kamus Besar Bahasa Indonesia.

\subsection{Teknik Analisis Data}

Data dan bahan hukum yang telah dideskripsikan selanjutnya ditentukan maknanya melalui metode interprestasi dalam usaha memberikan penjelasan atas kata atau istilah yang

\footnotetext{
${ }^{7}$ Nico Ngani,Metodologi Penelitian dan Penulisan Hukum, Pustaka Yustisia, Jakarta, 2012, h.71.

8 Ibrahim. SH, M.Hum., Dr. Johnny; Teori \& Mclode Penelitian Hukum Normaitf,. Bayumedia Publishing, Malang:, April 2005, h. 47.
} 
kurang jelas maksudnya terkait pokok permasalahan yang diteliti sehingga orang lain dapat memahaminya

\section{HASIL PENELITIAN DAN PEMBAHASAN}

\subsection{Analisis Bentuk Sengketa Perkara Nomor 2860/Pdt.G/2013/PA.Mr.}

Berdasarkan kondisi realitas dan fakta serta bukti dalam persdiangan tersebut maka majelis hakim melakukan persidangan yang mana diketahui bahwa:

Menimbang, bahwa karena permasalahan ini berhubungan dengan perjanjian/akad, khususnya perjanjian/akad ekonomi syariah dalam skema akad pembiayaan murabahah dan akad pembiayaan murabahah bil wakalah, maka dalam hal ini Majelis Hakim perlu mengetengahkan dalil al-Quran dan hadist yang selanjutnya diambil alih sebagai pendapat Majelis Hakim, tentang hukum melaksanakan akad/ perjanjian yang telah dibuat, yaitu :

Artinya : "Hai orang yang beriman, penuhilah akad-akad itu.” (Q.S Maidah : 1)

Artinya : "Kaum Muslim terikat pada perjanjian yang dibuatnya, kecuali perjanjian yang menghalalkan sesuatu yang haram atau mengharamkan sesuatu yang halal". (H.R. Tirmidzi)

Menimbang, bahwa dengan telah diterimanya Eksepsi Tergugat I, maka putusan ini merupakan putusan akhir (eind vonnis), sehingga Majelis Hakim tidak perlu lagi untuk mempertimbangkan Eksepsi yang telah disampaikan oleh Tergugat II dan Tergugat III, maupun eksepsi selain tentang kompetensi, dan sesuai dengan ketentuan pasal 134 HIR, maka Pengadilan Agama harus menyatakan tidak berwenang mengadili perkara ini;
Mendasari hal tersebut putusan majelis hakim pada saat persidangan dengan menentukan keputusan hakim terhadap perkara tersebut dituangkan dalam menangani perkara nomor : 2860/Pdt.G/2013/PA.Mr.

1. Menerima eksepsi Tergugat I;

2. Menyatakan Pengadilan Agama tidak berwenang mengadili perkara ini;

3. Menghukum kepada Para Penggugat untuk membayar biaya perkara sejumlah Rp. 1 . 496.000,- (satu juta empat ratus sembilan puluh enam ribu rupiah);

Keputusan yang ditetapkan hakim sudah melakukan upaya Menimbang, bahwa dengan telah diterimanya Eksepsi Tergugat I tentang kompetensi absolut (absolute competency), maka putusan ini merupakan putusan akhir (eind vonnis) sehingga Majelis Hakim tidak perlu mempertimbangkan tentang pokok perkara, yang telah dikemukakan dan dikaji dalam persidangan tersebut.

\subsection{Pertimbangan Hakim dan Kritikan Putusan Perkara Nomor 2860/Pdt.G/2013/PA.Mr.}

Putusan ini dari sisi hukum sudah sesuai dengan koridor dan ketentuan hukum yakni Bahwa majelis hakim menerima eksepsi tergugat dikarenakan eksepsi dari Tergugat I tentang kompetensi absolut (absolute competency) tersebut beralasan hukum, sehingga dapat diterima dan dikabulkan; serta diantara para pihak sudah ada kesepakatan dari para penggugat tidak akan mengajukan Gugatan ini ke Pengadilan Agama Mojokerto (sesuai eksepsi Tergugat I) apabila salinan Akad Pembiayaan Murabahah No. 72 tanggal 19 September 2011 yang dibuat dihadapan Notaris Dwi Rossuiliati. SH dan akad Pembiayaan Murabahah Bil Wakalah No. 73 
tanggal 19 September 2011 yang juga dibuat dihadapan Notaris Dwi Rossuiliati SH, diberikan oleh Tergugat I, Akan tetapi melalui Peraturan dan Prosedur BASYARNAS (Badan Arbitrase Syariah Nasional).

Pilihan hukum untuk penyelesaian perselisihan yang telah disepakati telah diatur dalam ketetentuan perundang-undangan yang berlaku yang mana dengan tegas apabila para pihak telah menentukan pilihan hukum untuk penyelesaian sengketa ke arbitrase,maka Pengadilan tidak berwenang mengadili perkara aquo.

Berdasarkan analisis peneliti, dengan permasalahan yang dikaji dalam penelitian ini, maka dapat dikemukakan bahwasanya keberadaan BRI syariah Cabang Mojokerto pada perkara ini yang secara nyata tidak memberikan penjelasan dan dampak hukum yang akan terjadi kepada nasabah secara detail berkaitan dengan resiko dari akad yang dilakukan nasabah dengan pihak PT. Bank BRI syariah menunjukkan masih lemahnya perlindungan hukum bagi nasabah perbankan syariah, hal ini dapat telah mendatangkan mafshadah yang lebih buruk terhadap nasabah yang berupaya menjalankan usaha dengan sistem ekonomi syariah.

Sejauh pemahaman penulis, kewenangan dalam penyelesaian sengketa Perbankan Syari'ah adalah merupakan kewenangan Peradilan Agama, karena sengketa Perbankan Syari'ah adalah merupakan salah satu sengketa ekonomi syari'ah, dan merupakan sengketa yang ada diantara orangorang Islam. sudah sewajarnya ketika urusan tersebut diselesaikan melalui Peradilan Agama.

\section{KESIMPULAN DAN SARAN}

\subsection{Kesimpulan}

1. Bentuk sengketa antara nasabah dan Bank BRI Syariah pada perkara nomor 2860/Pdt.G/2013/PA.Mr, di PA. Mojokerto adalah perkara yang mana Pengadilan Agama mempunyai kewenangan dalam menyelesaiakan sengketa ekonomi syariah. Sedangkan penyelesaian sengketa melalui jalur non litigasi maupun pengadilan (litigasi) adalah alternatif yang diperbolehkan oleh hukum, sehingga perkara ini bisa diselesaikan pada lembaga Basyarnas.

2. Keberadaan perlindungan hukum bagi nasabah bank syariah atas perkara nomor 2860/Pdt.G/2013/PA.Mr, dari analisis dapat dikemukakan bahwa masih terdapat realita perlindungan hokum bagi nasabah yang berpekara dalam perkara ekonomi syariah masih belum optimal mendapatkan perlindungan hokum oleh pihak yang berwenang menanganinya, hal ini juga dikeranakan masih banyak nasabah yang belum memahami penyelesaian hukum terhadap perkara hukum yang akan terjadi bila berkaitan dengan ekonomi syariah.

\subsection{Saran}

Berdasarkan hasil penelitian yang diperoleh, sehingga saran sebagai berikut:

1. Bagi pihak Bank (penggugat) dalam melakukan sebuah perjanjian pembiayaan dengan nasabahnya hendaknya lebih terbuka dan rinci serta lebih jeli menentukan akad yang akan digunakan dalam perjanjian pembiayaan dan lebih mempertimbangkan resiko yang mungkin terjadi. Hal ini untuk menghindari adanya kerugian fatal yang akan diderita pihak Bank ataupun nasabah 
bank tersebut ketika terjadi kasus wanprestasi. Dalam menuliskan akad pun harus jelas bentuk dan jenis akadnya. Agar tidak terjadi kesalah fahaman antara debitur dan kreditur dalam mengimplementasikan akad.

2. Bagi para hakim yang menangani perkara sengketa ekonomi syariah hendaknya lebih fleksibel dan tidak mengacu pada acuan hukum yang terbatas. Wawasan terhadap hal interaksi ekonomi dimasyarakat hendaknya lebih diperluas. Sehingga pada saat mempertimbangkan sebuah gugatan ekonomi tidak terkesan kaku dan dapat menghasilkan putusan yang adil serta tidak merugikan para pihak, baik itu pihak Bank maupun pihak Nasabah.

3. Diharapkan kepada peneliti selanjutnya semoga penelitiain ini tidak dianggap lengkap dan sempurna. Penyusun menyadari bahwa dari penelitian ini tentu masih banyak kekurangannya. Penelitian ini merupakan langkah awal yang diharapkan penelitian selanjutnya lebih konprehensif yang dilakukan peneliti-peneliti lain dalam membuka keterbatasan dari penelitian ini dan tentunya dilandasi sikap keterbukaan bahwa hukum itu berkembang menyesuaikan kebutuhan pada tempat dan waktu dimana hukum itu berada.

\section{DAFTAR PUSTAKA}

Ahmad Mujahidin, 2010, Prosedur Sengketa Ekonomi Syariah di Indonesia, Bogor, Ghalia Indonesia.

Bank Indonesia, 2008, Pedoman Akuntansi Perbankan Syariah Indonesia, Jakarta http://business-law.binus.ac.id/2015/02/17/

penyelesaian-sengketa-perbankan-syariah-diindonesia-bagian-1-dari-2-tulisan

Ibrahim. SH, M.Hum., Dr. Johnny; April 2005, Teori \& Mclode Penelitian Hukum Normaitf,. , Malang, Bayumedia Publishing.

Muhammad Abdullah Al-Arabi, 2000, Petunjuk Praktis Menjalankan Syariat Islam dalam Bermuamalah yang Sah Menurut Hukum Nasional, Jakarta, Studia Press,

Nico Ngani, 2012, Metodologi Penelitian dan Penulisan Hukum, Jakarta, Pustaka Yustisia.

ThalisNoor CJurnal Ekonomi Syariah Indonesia, Volume I, No.2 Desember 2011-16 